\title{
EXPERIMENTAL INVESTIGATION OF LM25 ALLOY REINFORCED WITH SiC, Gr AND MOA PARTICLES
}

\author{
EKSPERIMENTALNE RAZISKAVE NA A1 ZLITINI LM25, OJAČANI \\ Z DELCI SiC, GRAFITA IN PEPELA MORINGE
}

\author{
Dhanashekar Manickam, Senthil Kumar Velukkudi Santhanam*, Karthikeyan Sivagnanam \\ Anna University, Department of Mechanical Engineering, Chennai 600025, Tamil Nadu, India \\ Prejem rokopisa - received: 2018-03-09; sprejem za objavo - accepted for publication: 2018-12-20
}

doi: $10.17222 / \mathrm{mit} .2018 .038$

\begin{abstract}
An experimental investigation was performed on an LM25 aluminium alloy reinforced with silicon carbide (SiC), graphite (Gr) and moringa oleifera ash (MOA) particles. The composites with different proportions such as $5 w / \%$ of $\mathrm{SiC}, 5 \mathrm{w} / \%$ of $\mathrm{SiC}+$ $1 w / \%$ of Gr, $5 w / \%$ of $\mathrm{SiC}+3 w / \%$ of $\mathrm{Gr}, 5 w / \% \mathrm{SiC}+1 w / \% \mathrm{MOA}$, and $5 w / \%$ of $\mathrm{SiC}+3 w / \%$ of MOA were produced with the stir-casting method. The effects of the reinforcement particles on density, micro-hardness, grain size, porosity, particle distribution and microstructure were studied. A characterization study was made using optical microscopy (OP) and scanning electron microscopy (SEM). Based on the hardness and density results, the MOA-reinforced composites had better hardness and decreased porosity when compared to the Gr-reinforced composites. The MOA particles exhibited a homogeneous distribution in the matrix whereas the Gr particles had a few cluster formations.

Keywords: LM25 aluminium alloy, moringa oleifera ash, stir casting, mechanical properties
\end{abstract}

Avtorji opisujejo eksperimentalne raziskave na Al zlitini LM25, ojačani z delci silicijevega karbida (SiC), grafita (Gr) in pepela moringe (MOE, angl.: Moringa Oleifera Ash). Kompoziti so vsebovali različne deleže posameznih delcev, to je: 5 w/\% SiC $5 w / \% \mathrm{SiC}$ in $1 w / \% \mathrm{Gr}, 5 w / \% \mathrm{SiC}$ in $3 w / \% \mathrm{Gr}, 5 w / \% \mathrm{SiC}$ in $1 w / \% \mathrm{MOA}, 5 w / \% \mathrm{SiC}$ in $3 w / \%$ MOA. Kompozite so izdeloval s tehniko vmešavanja delcev v talino Al zlitine. Avtorji so nato raziskovali vpliv ojačitve (dodanih delcev) na gostoto, mikrotrdoto, velikost kristalnih zrn, poroznost in ostalo mikrostrukturo zlitine. Analize so izvedli z optično (OP) in vrstično elektronsko mikroskopijo (SEM) ter rentgensko strukturno analizo (XRD). Iz rezultatov meritev mikrotrdote in gostote ugotavljajo, da imajo z MOA ojačani kompoziti boljšo trdoto in manjšo poroznost v primerjavi z Gr ojačanimi kompoziti. Delci MOA so enakomerno porazdeljeni v kovinski osnovi zlitine, medtem ko so se delci Gr združevali oziroma tvorili skupke.

Ključne besede: zlitina na osnovi aluminija LM25, pepel moringe, postopek litja z vmešavanjem delcev v talino Al zlitine, mehanske lastnosti

\section{INTRODUCTION}

Aluminium-based composites with bio-organic particles as the reinforcement are a topic of interest for the researchers due to their low costs and improved mechanical properties. To date, researchers have investigated the effects of various natural wastes used as reinforcement particles such as fly ash, ${ }^{1,2}$ rice-husk ash, ${ }^{3}$ bean-pod ash, ${ }^{4}$ bamboo-leaf ash, red mud, groundnut-shell ash, ${ }^{5}$ melon-shell ash ${ }^{6}$ and bagasse ash ${ }^{7}$ as the substitutes for the commercial reinforcement particles for producing cost-effective and new composite materials. Mazahery Ali et al. ${ }^{8}$ examined the impact of nano-SiC particles incorporated in the A356 alloy and concluded that SiC particles enhanced the mechanical properties of composites. Liang-Jing Fan $^{1}$ studied the behaviour of fly-ash particles in the $\mathrm{Al}-3 \mathrm{Mg}$ melt at $850{ }^{\circ} \mathrm{C}$ and various durations such as $(0,10,20,30$ and 40$) \mathrm{h}$, and observed that the Si released from the fly ash and $\mathrm{Mg}$ undergoes a reduction reaction to form the $\mathrm{Mg}_{2} \mathrm{Si}$ phase. During a longer reaction, porous fly-ash particles decompose completely and decrease the porosity. Rajan ${ }^{2}$ examined

*Corresponding author e-mail:

vssk70@gmail.com (Senthil Kumar Velukkudi Santhanam) the significance of fine-ash particles in an aluminium alloy at a very high temperature of $1200{ }^{\circ} \mathrm{C}$; he found that the fly-ash particles undergo interfacial reactions with $\mathrm{SiO}_{2}$ and $\mathrm{Al}_{2} \mathrm{O}_{3}$, yielding the $\mathrm{MgAl}_{2} \mathrm{O}_{4}$ phase. Atuanya ${ }^{4}$ utilized the bean-pod ash as the reinforcement and showed there was a better interparticle bond strength in an $\mathrm{Al}-\mathrm{Cu}-\mathrm{Mg}$ alloy. Kenneth ${ }^{5}$ investigated the effects of groundnut-shell ash (GSA), rice-husk ash and bamboo-leaf ash along with silicon carbide as the reinforcement particles in an $\mathrm{Al}-\mathrm{Mg}-\mathrm{Si}$ alloy. GSA composites produced the highest mechanical properties among the ash particles. Abdulwahab ${ }^{6}$ utilized the melon-shell ash with 5, 10, 15, and 20-\% additions using the vortex method and observed a refined surface and better particle-matrix interface bond. Mohammed Imran ${ }^{7}$ attempted a study with sugarcane bagasse-ash and graphite particles as the reinforcement in the A17075 alloy and observed an increase in the hardness with an increase in the reinforcement. A composite with natural waste used as the reinforcing particles needs to have the proper mix ratio to obtain improved properties. In this experimental study, the stir-casting method was employed to manufacture particle-reinforced composites. To the best of the author's knowledge, moringa oleifera ash particles have not been used as the reinforcement 
Table 1: Chemical compositions of the LM25 alloy and MOA particles

\begin{tabular}{|c|c|c|c|c|c|c|c|c|c|c|c|}
\hline Elements & $\mathrm{Cu}$ & $\mathrm{Si}$ & $\mathrm{Mg}$ & $\mathrm{Mn}$ & $\mathrm{Fe}$ & $\mathrm{Ti}$ & $\mathrm{Ni}$ & $\mathrm{Zn}$ & $\mathrm{Pb}$ & $\mathrm{Sn}$ & $\mathrm{Al}$ \\
\hline LM25 alloy $(w / \%)$ & 0.02 & 6.99 & 0.48 & 0.02 & 0.22 & 0.18 & 0.01 & 0.04 & $<0.001$ & 0.001 & Balance \\
\hline Elements & $\mathrm{SiO}_{2}$ & $\mathrm{Al}_{2} \mathrm{O}_{3}$ & $\mathrm{Fe}_{2} \mathrm{O}_{3}$ & $\mathrm{TiO}_{2}$ & $\mathrm{P}_{2} \mathrm{O}_{5}$ & $\mathrm{CaO}$ & $\mathrm{MgO}$ & $\mathrm{Na}_{2} \mathrm{O}$ & $\mathrm{K}_{2} \mathrm{O}$ & \multicolumn{2}{|c|}{$\mathrm{SO}_{3}$} \\
\hline MOA particles $(w / \%)$ & 1.22 & 0.024 & 0.045 & $<0.001$ & 0.03 & 0.33 & 0.24 & 0.11 & 1.07 & 0.19 \\
\hline
\end{tabular}

particles with an LM25 alloy. Based on a literature survey, we can say that meagre information is available on multiple particles used with the LM25 alloy and the use of MOA as reinforcement particles. An experimental investigation was conducted on the LM25 alloy reinforced with two different secondary reinforcements, i.e., Gr and MOA particles, and a comparative study of their effects on the physical, microstructural and mechanical properties of the composite materials was made.

\section{EXPERIMENTAL PART}

The LM25 alloy was selected as the matrix; its chemical composition is specified in Table 1. Silicon carbide ( $\mathrm{SiC})$, graphite (Gr) and moringa oleifera ash (MOA) particles were the primary and secondary reinforcements. Dried moringa oleifera was calcined at $750{ }^{\circ} \mathrm{C}$ for $5 \mathrm{~h}$. The ash obtained was mixed with a $2.5 \mathrm{~mol} \mathrm{NaOH}$ solution and boiled at $75{ }^{\circ} \mathrm{C}$ for $3 \mathrm{~h}$ with magnetic stirring. Then the filtered precipitate was dried and mixed with a $2 \% \mathrm{HCl}$ solution, refluxing at $75{ }^{\circ} \mathrm{C}$ for $4 \mathrm{~h}$. Finally, the precipitate was collected, cleaned and dried at $110{ }^{\circ} \mathrm{C}$ for $10 \mathrm{~h} .{ }^{4}$ The synthesized ash particles were free from impurities and surface treated. The key elements present in the moringa oleifera ash were analysed and their values in $w / \%$ are shown in Table 1. The LM25 alloy was melted to $800{ }^{\circ} \mathrm{C}$ in an electric furnace and a hexachloroethane degasser was used to remove dissolved hydrogen. ${ }^{9}$ Particle wettability in the melt was improved with an inclusion of $1 \mathrm{w} / \%$ of pure $\mathrm{Mg}$. The reinforcement particles were preheated to $250{ }^{\circ} \mathrm{C}$ to remove moisture and a chromium-coated A310 stainless-steel stirrer was added at periodic intervals, stirring the melt at a varying speed of 450-700 $\mathrm{min}^{-1}$. A higher stirring speed caused a homogeneous distribution of the particles ${ }^{10}$ and a variation in the speed helped to limit the particle settlement at the bottom. The steel die was preheated to $250{ }^{\circ} \mathrm{C}$ to maintain a uniform cooling rate. Specific notations were determined for the composites such as $\mathrm{A}-(5 w / \% \mathrm{SiC}), \mathrm{B}-(5 w / \% \mathrm{SiC}+1$ $w / \% \mathrm{MOA}), \mathrm{C}-(5 w / \% \mathrm{SiC}+3 w / \% \mathrm{MOA}), \mathrm{D}-(5 w / \%$ $\mathrm{SiC}+1 w / \% \mathrm{Gr})$ and $\mathrm{E}-(5 w / \% \mathrm{SiC}+3 w / \% \mathrm{Gr})$. Density measurements were made using the Archimedean principle and comparing the weights of the samples immersed in air and distilled water. ${ }^{8}$ The rule-of-mixtures relation, as given in Equations $(1,2)$, was applied to calculate the theoretical density and porosity \%, respectively. The hardness was measured using a Vickers hardness-testing machine operated at a load of $200 \mathrm{gm}$, and the average of ten measurements from different points on a sample was taken. An XRD peak analysis performed with an X'PERT-PRO X-ray diffractometer operated at a scanning rate of $0.02{ }^{\circ} \mathrm{min}^{-1}$, wavelength of $0.15406 \mathrm{~nm}$, generator setting of $45 \mathrm{kV}$ and $40 \mathrm{~mA}$ was used to study the metallurgical changes. The composites were mirror polished and etched using Keller's reagent prior to optical and SEM examinations.

$$
\begin{gathered}
d_{\mathrm{th}}=d_{\mathrm{m}} \times V_{\mathrm{m}}+d_{\mathrm{r} 1} \times V_{\mathrm{r} 1}+d_{\mathrm{r} 2} \times V_{\mathrm{r} 2} \\
\text { Porosity }=\frac{d_{\mathrm{th}}-d_{\mathrm{mc}}}{d_{\mathrm{th}}} \times 100(\%)
\end{gathered}
$$

Here $d_{\mathrm{th}}, d_{\mathrm{mc}}, d_{\mathrm{m}}, d_{\mathrm{r} 1}, d_{\mathrm{r} 2}$ stand for the theoretical density, measured density, matrix density, reinforcement 1 density and reinforcement 2 density while $V_{\mathrm{m}}, V_{\mathrm{r} 1}, V_{\mathrm{r} 2}$ stand for the volume fraction of the matrix, reinforcement 1 and reinforcement 2 , respectively.

\section{RESULTS AND DISCUSSION}

\subsection{Density, porosity and Vickers hardness}

An addition of moringa oleifera ash particles to the composites decreases the density but the porosity formation is minimal when compared to the graphite-mixed composites. An increase in the addition of Gr particles leads to an increase in the porosity $\%$, which agrees with the result of the study by Mishra. ${ }^{11}$ From Table 2, it is clear that the porosity increases as the $w / \%$ of graphite increases owing to the poor wettability and the graphite particles being clustered near the silicon carbide particles. On the contrary, the MOA particles exhibit a better wettability with the matrix; thereby the porosity $\%$ is minimal. From Table 2, it is clear that the hardness decreases with an increase in the graphite and MOA particles. Single-reinforcement composite A exhibits a higher hardness compared to the ones with dual reinforcements. The MOA-reinforced composites have a higher hardness than the Gr-reinforced ones because of the formation of the strengthening phase $\mathrm{Mg}_{2} \mathrm{Si}$ and the microstructural refinement. This grain refinement is ascribed to the increase in the hardness of the MOA-reinforced composites.

\subsection{Microstructural characterization}

Figure 1 (a-f) shows the microstructures of the LM25 alloy and composites A, B, C, D and E, respectively, consisting of $\mathrm{Al}$ dendrites and eutectic Si. The microstructure examination reveals the dispersed MOA particles at the primary $\alpha$-aluminium grain interface. Composites $\mathrm{B}$ and $\mathrm{C}$ show no evidence of a cluster formation of the MOA particles. The average grain size 

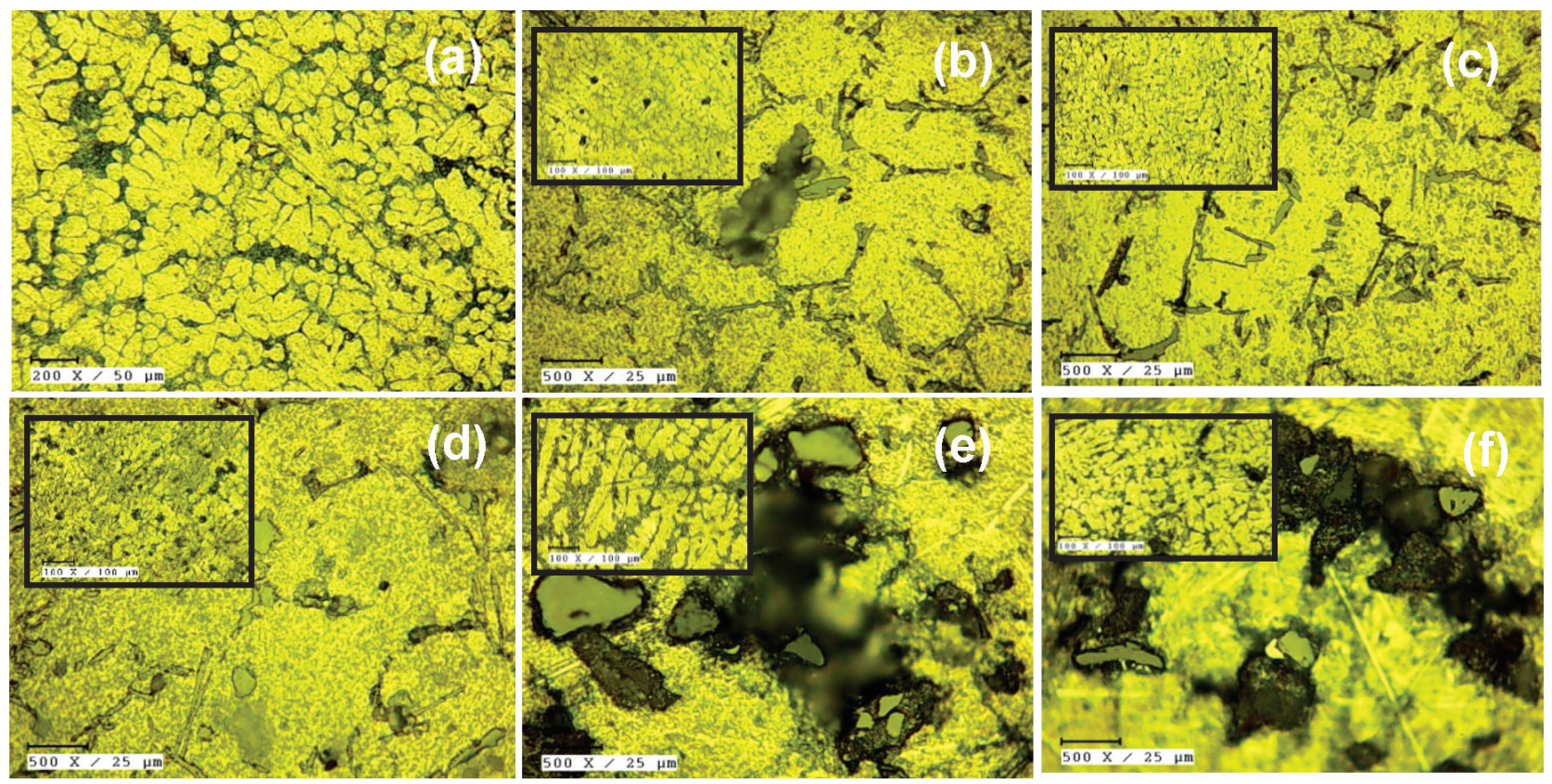

Figure 1: Optical microstructures of the stir-cast alloy and composites a) LM25 alloy, b) composite A, c) composite B, d) composite C, e) composite $\mathrm{D}$, and f) composite $\mathrm{E}$ at $500 \times$ mag. $/ 25 \mu \mathrm{m}$ (the insert graph at a magnification of $100 \times / 100 \mu \mathrm{m}$ )
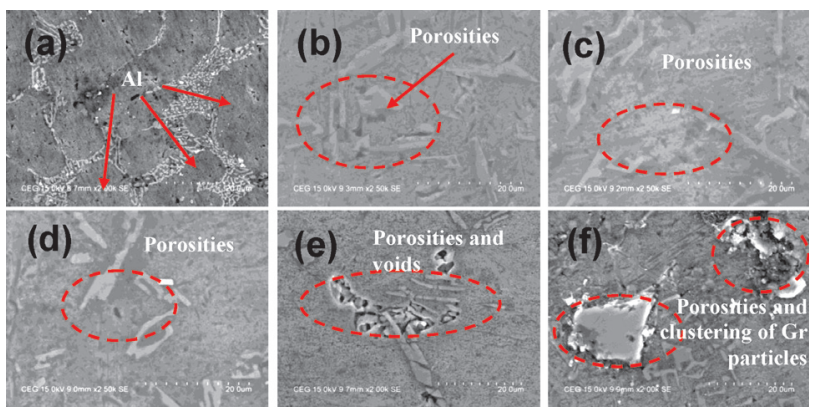

Figure 2: SEM images of the LM25 alloy and composites: a) LM25 alloy, b) composite A, c) composite B, d) composite C, e) composite $\mathrm{D}$, and $\mathrm{f}$ ) composite $\mathrm{E}$

and circularity were measured using the ImageJ analysis software $^{12}$ and the values are given in Table 2 . The circularity value is high for the MOA-particle-reinforced composites when compared to the base alloy and the other composites. The circularity is used to define the roundness of the grains (cylindrical shape) and a higher value provides a better strength. The grain shape has an effect on Young's modulus due to the difference between the volume fractions of the grain boundaries with different grain shapes. ${ }^{13}$

Figure 2 (e, f) depicts SEM images of the composites, displaying the formation of particle clusters for the graphite-reinforced composites. Figures $\mathbf{2 c}$ and $\mathbf{2 d}$ show a better wettability of the MOA particles with the matrix, which hinders the growth of the secondary dendrite arm spacing; as a result, finer grains are formed. The MOA particles act as grain refiners and similar results were observed by Kanth et al. ${ }^{14}$ who studied the effect of fly ash/SiC particles reinforcing Al-Zn alloy based composites fabricated with the stir-casting method. As shown in Equation (3), $\mathrm{Si}$ and $\mathrm{Mg}$ react to form $\mathrm{Mg}_{2} \mathrm{Si}$ strengthening precipitates in the MOA composites, which was confirmed with an XRD analysis as shown in Figure 3. The composites reinforced with $\mathrm{SiC}$ and $\mathrm{Gr}$ particles favour the formation of a brittle $\mathrm{Al}_{4} \mathrm{C}_{3}$ compound according to Equations $(4,5)$, and graphite particles have a weak interface bonding with the matrix, which ultimately decreases the material properties.

$$
\begin{gathered}
\mathrm{Si}+2 \mathrm{Mg} \rightarrow \mathrm{Mg}_{2} \mathrm{Si} \\
4 \mathrm{Al}+3 \mathrm{C} \rightarrow \mathrm{Al}_{4} \mathrm{C}_{3}
\end{gathered}
$$

\begin{tabular}{|c|c|c|c|c|c|c|c|}
\hline \multirow{2}{*}{ S. No. } & \multirow{2}{*}{ Composite } & \multirow{2}{*}{$\begin{array}{c}\text { Theoretical } \\
\text { density }\left(\mathrm{g} / \mathrm{cm}^{3}\right)\end{array}$} & \multirow{2}{*}{$\begin{array}{l}\text { Measured density } \\
\left(\mathrm{g} / \mathrm{cm}^{3}\right)\end{array}$} & \multirow{2}{*}{$\begin{array}{l}\text { Porosity } \\
(\%)\end{array}$} & \multirow{2}{*}{$\begin{array}{c}\text { Vickers hardness } \\
(\mathrm{Hv})\end{array}$} & \multicolumn{2}{|c|}{ Average } \\
\hline & & & & & & Grain size in $\mu \mathrm{m}^{2}$ & Circularity $\%$ \\
\hline 1 & LM25 alloy & 2.66 & 2.7 & 0.54 & 67.5 & 47.78 & 0.24 \\
\hline 2 & $\mathrm{~A}$ & 2.70 & 2.68 & 0.71 & 91 & 40.3 & 0.62 \\
\hline 3 & B & 2.45 & 2.42 & 1.41 & 84 & 35.68 & 0.66 \\
\hline 4 & $\mathrm{C}$ & 2.06 & 1.99 & 3.21 & 77 & 34.78 & 0.66 \\
\hline 5 & $\mathrm{D}$ & 2.62 & 2.5 & 4.41 & 80.5 & 48.05 & 0.57 \\
\hline 6 & $\mathrm{E}$ & 2.51 & 2.32 & 7.62 & 71 & 38.1 & 0.53 \\
\hline
\end{tabular}

Table 2: Density, porosity, micro-hardness, grain size and circularity values for the LM25 alloy and the composites 


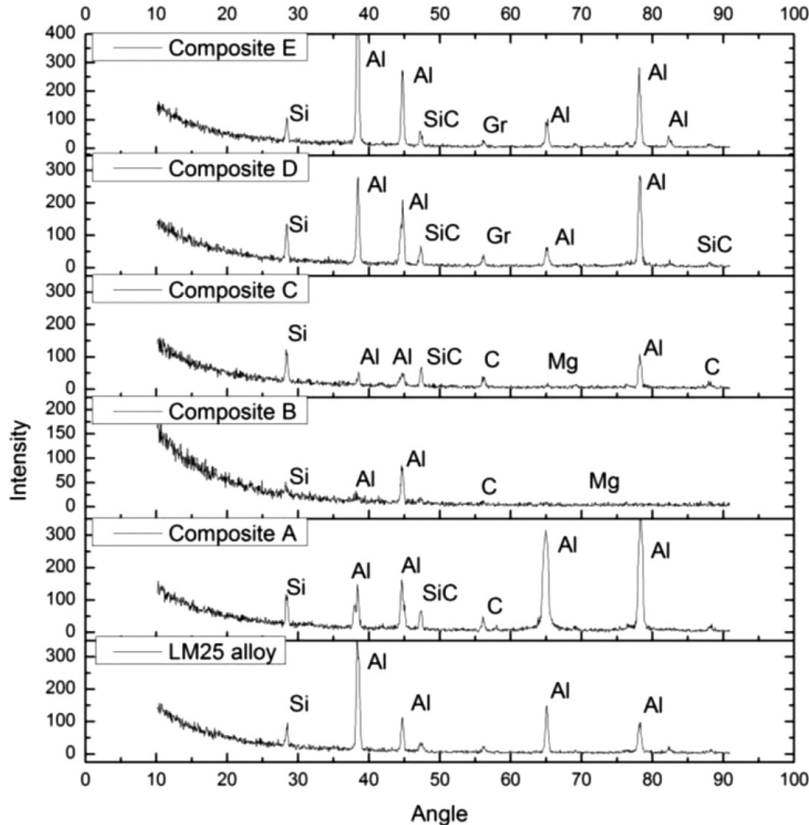

Figure 3: XRD patterns of the LM25 alloy and composites: a) LM25 alloy, b) composite $\mathrm{A}, \mathrm{c}$ ) composite $\mathrm{B}$, d) composite $\mathrm{C}$, e) composite $\mathrm{D}$, and f) composite $\mathrm{E}$

$$
4 \mathrm{Al}+3 \mathrm{SiC} \rightarrow \mathrm{Al}_{4} \mathrm{C}_{3}+3 \mathrm{Si}
$$

Figure 3 shows XRD plots for the prepared composites and the patterns exhibit a complete particle distribution in the matrix. From the XRD results, it is observed that the moringa ash particles influenced the aluminium phase as the peak intensity is reduced and the overall intensity peaks are reduced in Composites B and C. The XRD results also confirm that there was no formation of secondary phases. The aluminium peaks for Composites $\mathrm{B}$ and $\mathrm{C}$ (with moringa oleifera ash particles) are shifted to higher $2 \theta$ values in comparison to the LM25 alloy. This result is similar to that obtained by Praveen ${ }^{15}$ who fabricated aluminium-matrix composites with bamboo leaf ash particles.

\section{CONCLUSIONS}

Moringa oleifera ash reinforced composites enhance the evolution of $\mathrm{Mg}_{2} \mathrm{Si}$ precipitates and grain refinement. Graphite reinforced composites contain $\mathrm{Al}_{4} \mathrm{C}_{3}$ precipitates, which retard the material properties because of their brittle nature. The moringa oleifera ash reinforced composites exhibit a decrease in the porosity \% when compared to the graphite reinforced composites. The porosity of the moringa oleifera ash reinforced composites was reduced by $81.5 \%$ compared to the graphite reinforced composites. Composite A with a single reinforcement shows a higher hardness of $91 \mathrm{Hv}$, followed by Composite B with MOA particles. An increase in the secondary reinforcement particles decreased the hardness of the composites.

\section{REFERENCES}

${ }^{1}$ L.-J. Fan, S. H. Juang, Reaction effect of fly ash with Al-3Mg melt on the microstructure and hardness of aluminum matrix composites, Mater. Des., 89 (2016), 941-949, doi:10.1016/j.matdes.2015.10.070

${ }^{2}$ T. P. D. Rajan, R. M. Pillai, B. C. Pai, K. G. Satyanarayana, P. K. Rohatgi, Fabrication and characterisation of Al-7Si-0.35Mg/fly ash metal matrix composites processed by different stir casting routes, Compos. Sci. Technol., 67 (2007), 3369-3377, doi:10.1016/ j.compscitech.2007.03.028

${ }^{3}$ G. Narasaraju, D. Linga Raju, Characterization of hybrid rice husk and fly ash-reinforced aluminium alloy (AlSi10Mg) composites, Mater. Today, 2 (2015), 3056-3064, doi:10.1016/j.matpr.2015.07.245

${ }^{4}$ C. U. Atuanya, V. S. Aigbodion, Evaluation of Al-Cu-Mg alloy/bean pod ash nanoparticles synthesis by double layer feeding-stir casting method, J. Alloys Compd., 601 (2014), 251-259, doi:10.1016/ j.jallcom.2014.02.086

${ }^{5}$ K. K. Alaneme, M. O. Bodunrin, A. A. Awe, Microstructure, mechanical and fracture properties of groundnut shell ash and silicon carbide dispersion strengthened aluminium matrix composites, Journal of King Saud University - Engineering Sciences, 30 (2018), 96-103, doi:10.1016/j.jksues.2016.01.001

${ }^{6}$ M. Abdulwahab, O. B. Umaru, M. A. Bawa, H. A. Jibo, Microstructural and thermal study of Al-Si-Mg/melon shell ash particulate composite, Results in Physics, 7 (2017), 947-954, doi:10.1016/j.rinp. 2017.02.016

${ }^{7}$ M. Imran, A. R. Anwar Khan, S. Megeri, S. Sadik, Study of hardness and tensile strength of Aluminium-7075 percentage varying reinforced with graphite and bagasse-ash composites, Resource-Efficient Technologies, 2 (2016), 81-88, doi:10.1016/j.reffit.2016.06.007

${ }^{8}$ M. Ali, M. O. Shabani, Characterization of cast A356 alloy reinforced with nano SiC composites, Trans. Nonferrous Met. Soc. China, 22 (2012), 275-280, doi:10.1016/S1003-6326(11)61171-0

${ }^{9}$ S. Basavaraju, K. Arasukumar, B. Chandrashekhar, C. K. Umesh, Studies on mechanical properties and tribological characteristics of LM25-graphite-silicon carbide and LM25-flyash-silicon carbide hybrid MMCs, International Journal of Innovative Research in Science, Engineering and Technology, 1 (2012), 107-112

${ }^{10}$ S. Balasivanandha Prabu, L. Karunamoorthy, S. Kathiresan, B. Mohan, Influence of stirring speed and stirring time on distribution of particles in cast metal matrix composites, J. Mater. Process. Technol., 171 (2006), 268-273, doi:10.1016/j.jmatprotec.2005.06. 071.

${ }^{11}$ S. K. Mishra, S. Biswas, A. Satapathy, A study on processing, characterization and erosion wear behavior of silicon carbide particle filled ZA-27 metal matrix composites, Mater. Des., 55 (2014), 958-965, doi:10.1016/j.matdes.2013.10.069

${ }^{12}$ J. Schindelin, I. Arganda-Carreras, E. Frise, V. Kaynig, M. Longair, T. Pietzsch, S. Preibisch, C. Rueden, S. Saalfeld, B. Schmid, J. Y. Tinevez, D. J. White, V. Hartenstein, K. Eliceiri, P. Tomancak, A. Cardona, Fiji: an open-source platform for biological-image analysis, Nature Methods, 9 (2012), 676-682

${ }^{13}$ K. Zhou, B. Liu, Y. Yao, K. Zhong, Effects of grain size and shape on mechanical properties of nanocrystalline copper investigated by molecular dynamics, Materials Science and Engineering A, 615 (2014), 92-97, doi:10.1016/j.msea.2014.07.066

${ }^{14}$ U. R. Kanth, P. S. Rao, M. G. Krishna, Mechanical behaviour of fly ash/SiC particles reinforced Al-Zn alloy-based metal matrix composites fabricated by stir casting method, J. Mater. Res. Technol., 8 (2019), 737-744, doi:10.1016/j.jmrt.2018.06.003

${ }^{15}$ B. Praveen Kumar, B. Anil Kumar, Microstructure and mechanical properties of aluminium metal matrix composites with addition of bamboo leaf ash by stir casting method, Trans. Nonferrous Met. Soc. China, 27 (2017), 2555-2572, doi:10.1016/S1003-6326(17)60284-X 